Elizabeth C Hsia Shareholder of: Johnson \& Johnson, Employee of: Janssen Research \& Development, LLC, Alexa Kollmeier Shareholder of: Johnson \& Johnson, Employee of: Janssen Research \& Development, LLC, Xie L Xu Shareholder of: Johnson \& Johnson, Employee of: Janssen Research \& Development, LLC, Chetan Karyekar Shareholder of: Johnson \& Johnson, Employee of: Janssen Global Services, LLC, May Shawi Shareholder of: Johnson \& Johnson, Employee of: Janssen Global Services, LLC, Wim Noel Shareholder of: Johnson \& Johnson, Employee of: Janssen Scientific Affairs, LLC, Yusang Jiang Employee of: Cytel, Inc. providing statistical support (funded by Janssen), Shihong Sheng Shareholder of: Johnson \& Johnson, Employee of: Janssen Research \& Development, LLC, Yanli Wang Employee of: IQVIA providing statistical support (funded by Janssen), Philip J Mease Consultant of: AbbVie, Amgen, Boehringer Ingelheim, Bristol Myers Squibb, Eli Lilly, Galapagos, Gilead, GlaxoSmithKline, Janssen, Novartis, Pfizer, SUN, and UCB, Grant/research support from: AbbVie, Amgen, Bristol Myers Squibb, Eli Lilly, Galapagos, Gilead, Janssen, Novartis, Pfizer, SUN, and UCB.

DOI: 10.1136/annrheumdis-2021-eular.167

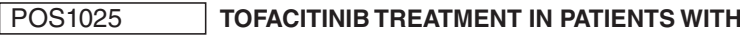 PSORIATIC ARTHRITIS AND PROBABLE DEPRESSION AND/OR ANXIETY: A POST HOC ANALYSIS OF TWO PHASE 3 CLINICAL TRIALS}

L. Gossec ${ }^{1}$, G. Citera ${ }^{2}$, A. Sellas-Fernández ${ }^{3}$, D. C. Gruben ${ }^{4}$, M. Valderrama ${ }^{5}$ S. Gómez ${ }^{5}{ }^{1}$ Sorbonne UniversitélHôpital Pitié-Salpêtrière, Paris, France; ${ }^{2}$ Instituto de Rehabilitación Psicofísica, Section of Rheumatology, Buenos Aires, Argentina; ${ }^{3}$ University Hospital Vall d'Hebron, Secció de Reumatologia, Barcelona, Spain; ${ }^{4}$ Pfizer Inc, Inflammation and Immunology, Groton, CT, United States of America; ${ }^{5}$ Pfizer Inc, Inflammation and Immunology, Madrid, Spain

Background: Depression and anxiety are highly prevalent in patients (pts) with psoriatic arthritis (PsA), ${ }^{1}$ with inflammation a key pathogenic feature of depression in these pts. ${ }^{2}$ Tofacitinib is an oral Janus kinase inhibitor for the treatment of PsA. It acts by modulating immune and inflammatory responses. The link between major depressive disorder/generalised anxiety disorder (MDD/GAD), inflammation and tofacitinib effectiveness has not been fully explored.

Objectives: Analyse the prevalence of probable MDD/GAD in pts with PsA initiating tofacitinib treatment and the impact of baseline (BL) probable MDD/GAD status on tofacitinib efficacy in these pts.

Methods: This was a post hoc analysis of data from pts who received tofacitinib 5 or $10 \mathrm{mg}$ twice daily (BID), or placebo (PBO), pooled from two Phase 3 trials (12-month OPAL Broaden [NCT01877668]; 3 6-month OPAL Beyond $[\text { NCT01882439] }]^{4}$ ). Pts with BL probable MDD and/or GAD were identified by a Short Form-36 Health Survey (SF-36) Mental Component Summary score (MCS) $\leq 38$. Pt demographics/BL characteristics and outcomes were stratified by the presence (SF-36 MCS $\leq 38$ ) or absence (SF-36 MCS $>38$ ) of BL probable MDD/GAD. At Months (M) $3 / 6 / 9 / 12$, changes from BL in SF-36 MCS were evaluated, and efficacy assessed by the proportions of pts who achieved: Psoriatic Arthritis Disease Activity Score (PASDAS) $\leq 3.2$, Health Assessment Questionnaire-Disability Index (HAQ-DI) improvement $\geq 0.35$ and Functional Assessment of Chronic Illness Therapy-Fatigue (FACIT-F) improvement $\geq 4$. BL global pain was measured via visual analogue scale.

Results: Of the 706 pts included in this analysis, BL probable MDD/GAD was identified in $46.2 \%, 44.9 \%$ and $46.2 \%$ of pts in the tofacitinib $5 \mathrm{mg} \mathrm{BID}(108 / 234)$, tofacitinib $10 \mathrm{mg}$ BID (106/236) and PBO (109/236) groups, respectively. BL disease activity was similar across the three treatment groups, independent of probable MDD/GAD status (mean PASDAS: 6.1-6.4 in pts with vs 5.8-6.1 in pts without probable MDD/GAD). In the tofacitinib $5 \mathrm{mg} B I D$ group, mean $B L$ scores for HAQ-DI (1.4 vs 1.0), FACIT-F total score (20.5 vs 32.4 ) and global pain (61.3 vs 51.5 ) indicated worse disability, fatigue and pain, respectively, for pts with vs without BL probable MDD/GAD. Similar findings were seen in the tofacitinib $10 \mathrm{mg}$ BID and PBO groups. At M3, improvements from BL in SF-36 MCS in pts with probable MDD/GAD were numerically, but not significantly, greater with tofacitinib 5 and $10 \mathrm{mg} \mathrm{BID}$ vs PBO, and these changes were largely sustained to M12 (Figure 1a). At M3, numerically greater proportions of pts achieved improvements in PASDAS, HAQ-DI and FACIT-F with tofacitinib 5 or $10 \mathrm{mg} B I D$ vs PBO, regardless of $\mathrm{BL}$ probable MDD/GAD status (Figure $1 \mathrm{~b}-\mathrm{d}$ ). Through M3-12, the proportions of pts who achieved PASDAS $\leq 3.2$ with tofacitinib 5 or $10 \mathrm{mg}$ BID were generally significantly greater in pts without vs with probable MDD/GAD (Figure 1b). At all timepoints, rates of improvement in HAQ-DI with tofacitinib $5 \mathrm{mg}$ BID were numerically greater in pts with vs without probable MDD/GAD, whereas the opposite was true for tofacitinib $10 \mathrm{mg}$ BID (Figure 1C). FACIT-F improvement rates with tofacitinib $10 \mathrm{mg}$ BID were consistently numerically greater in pts with vs without probable MDD/GAD, while findings were mixed for tofacitinib $5 \mathrm{mg} \mathrm{BID}$ (Figure 1d).

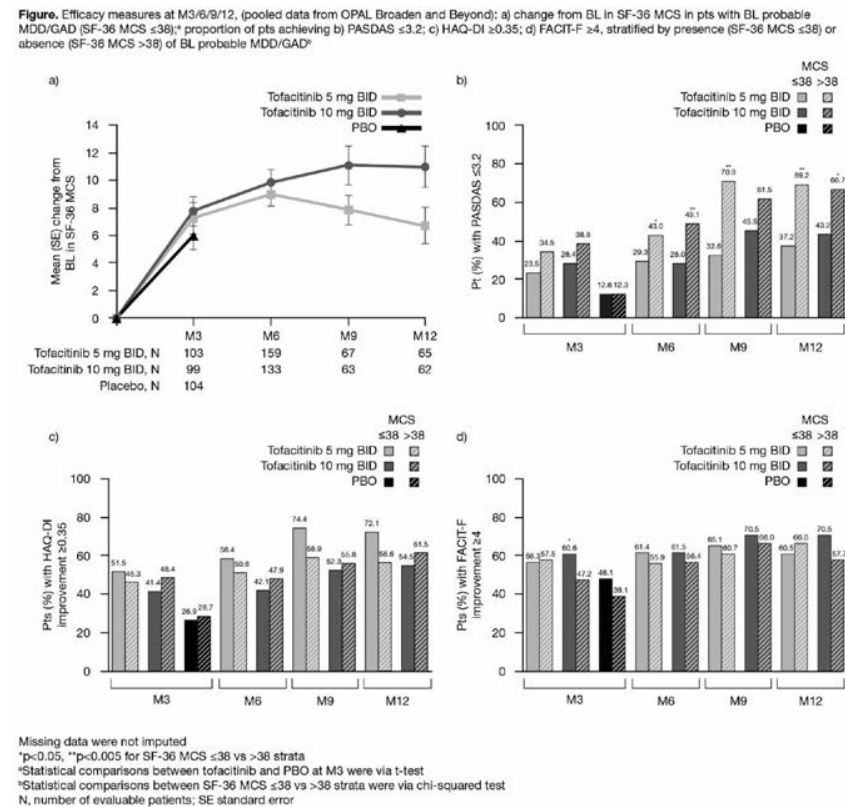

Conclusion: Around $46 \%$ of pts with PsA treated with tofacitinib had BL probable MDD/GAD (SF-36 MCS $\leq 38$ ). Pts with BL probable MDD/GAD treated with tofacitinib had sustained changes in SF-36 MCS. Rates of clinical improvement with tofacitinib were generally greater in pts without vs with probable MDD/GAD, whereas findings for disability and fatigue improvements varied between tofacitinib doses. Further research is required to evaluate the relationship between PsA and depression, to improve treatment targets and the quality of life of pts with PsA.

REFERENCES:

[1] Zhao et al. Clin Rheumatol 2020; 39: 217-225.

[2] Mathew \& Chandran. Rheumatol Ther 2020; 7: 287-300.

[3] Mease et al. N Engl J Med 2017; 377: 1537-1550.

[4] Gladman et al. N Engl J Med 2017; 377: 1525-1536.

Acknowledgements: Study sponsored by Pfizer Inc. Medical writing suppor was provided by Emma Deeks, CMC Connect, and funded by Pfizer Inc. Disclosure of Interests: Laure Gossec Grant/research support from: AbbVie Bristol-Myers Squibb, Celgene, Janssen, Eli Lilly, Novartis, Pfizer Inc, Roche, UCB, Gustavo Citera Consultant of: AbbVie, Amgen, Eli Lilly, Gema, Genzyme, Novartis, Pfizer Inc, Sanofi Genzyme, Grant/research support from: AbbVie, Amgen, Eli Lilly, Gema, Genzyme, Novartis, Pfizer Inc, Sanofi Genzyme, Agustí Sellas-Fernández: None declared, David C Gruben Shareholder of: Pfize Inc, Employee of: Pfizer Inc, Monica Valderrama Shareholder of: Pfizer Inc Employee of: Pfizer Inc, Susana Gómez Shareholder of: Pfizer Inc, Employee of: Pfizer Inc.

DOI: 10.1136/annrheumdis-2021-eular.176

\section{POS1026 GUSELKUMAB PROVIDES SUSTAINED IMPROVEMENTS IN WORK PRODUCTIVITY AND NON-WORK ACTIVITY IN PATIENTS WITH PSORIATIC ARTHRITIS: RESULTS THROUGH 1 YEAR OF A PHASE 3 TRIAL}

J. Curtis ${ }^{1}$, I. Mcinnes ${ }^{2}$, S. Peterson ${ }^{3}$, P. Agarwal ${ }^{4}$, F. Yang ${ }^{3}$, A. Kollmeier ${ }^{5}$ E. C. Hsia ${ }^{6,7}$, C. $\mathrm{Han}^{6}$, W. Tillett ${ }^{8}$, P. J. Mease ${ }^{9}$, P. Rahman ${ }^{10} .{ }^{1}$ University of Alabama at Birmingham, Department of Medicine, Immunology and Rheumatology, Birmingham, United States of America; ${ }^{2}$ University of Glasgow, Institute of Infection, Immunity \& Inflammation, Glasgow, United States of America; ${ }^{3}$ Janssen Global Services, LLC, Immunology, Horsham, United States of America; ${ }^{4}$ Janssen Research \& Development, LLC, Biostatistics, Spring House, United States of America; ${ }^{5}$ Janssen Research \& Development, LLC, Immunology, San Diego, United States of America; ${ }^{6} \mathrm{Janssen}$ Research \& Development, LLC, Immunology, Spring House, United States of America; ${ }^{7}$ University of Pennsylvania Medical Center, Rheumatology, Philadelphia, United States of America; ${ }^{8}$ Royal National Hospital for Rheumatic Diseases, Department of Pharmacy \& Pharmacology Centre for Therapeutic Innovation, Bath, United Kingdom; ${ }^{9}$ Swedish Medical Center/Providence St. Joseph Health and University of Washington School of Medicine, Rheumatology Research, Seattle, United States of America; ${ }^{10}$ Memorial University of Newfoundland, Craig L Dobbin Genetics Research Centre, St. John's, Canada 
Background: DISCOVER-2 was a Phase 3 trial of the first-in-class anti-IL-23specific mAb guselkumab (GUS) in patients (pts) with psoriatic arthritis (PsA). PSA impacts patients' productivity at work and in daily activity. 1

Objectives: To evaluate the effect of GUS on work productivity and daily activity in DISCOVER-2 through 1 year using the Work Productivity and Activity Impairment Questionnaire: PsA (WPAl- PsA).

Methods: Bio-naïve adults with active PsA despite nonbiologic DMARDs \&/ or NSAIDs received subcutaneous GUS $100 \mathrm{mg}$ every 4 weeks (Q4W); GUS $100 \mathrm{mg}$ W0, W4, then Q8W; or placebo (PBO). At W24, PBO pts crossed over to GUS $100 \mathrm{mg}$ Q4W. WPAI-PsA assesses PsA-related work time missed (absenteeism), impairment while working (presenteeism), impaired overall work productivity (absenteeism + presenteeism), and daily activity during the previous week. A shift analysis evaluated proportions of pts employed vs unemployed (regardless of desire to work) over time. Among pts working at baseline, least-squares (LS) mean changes from baseline in WPAI-PsA domains were determined using a mixed-effects model for repeated measures analysis, whereby mean changes in WPAI-PsA domains were calculated for each multiple imputation (MI) dataset using an analysis of covariance (ANCOVA); the reported LSmean is the average of all MI datasets. Also, among pts employed at baseline, indirect savings from improved overall work productivity were estimated using 2020 EU mean yearly wage estimate (all occupations). 2

Results: In pts working at baseline, significant improvement in work productivity and non-work activity vs PBO was observed at W24. Productivity gains seen with GUS at W24 continued to improve through 1 year (Table 1). Shift analysis showed relatively stable employment in pts employed at baseline $(62 \%$ of shift analysis cohort) through 1 year of GUS (>91\% continued to work when assessed at W16, W24, and W52 [data not shown]). For those unemployed at baseline (38\% of cohort), the proportion of pts working increased by $\sim 10 \%$ following 1 year of GUS (Figure 1). Potential yearly indirect savings from improved overall work productivity were: $€ 7409$ GUS Q4W and $€ 7039$ GUS Q8W vs $€ 4075$ PBO at W24 and were €8520 GUS Q4W, €9632 GUS Q8W, and €6668 $\mathrm{PBO} \rightarrow$ GUS Q4W at W52.

Conclusion: Improvement in work productivity and non-work activity was greater with GUS vs PBO among pts with active PsA through W52. Improvements demonstrated may result in reduction in PsA costs associated with work productivity.

REFERENCES:

[1] Tillett W et al. Rheumatol (Oxford). 2012;51:275-83.

[2] OECD (2020). Average wages (indicator). https://data.oecd.org/earnwage/ average-wages.htm

Table 1. Model-based estimates of LSmean change ${ }^{a}(95 \% \mathrm{CI})$ from baseline in WPAI-PsA domains among pts working at baseline and with an observed change through W24 ( $=474)$ and W52 ( $=475)$

\begin{tabular}{|c|c|c|c|c|c|c|}
\hline \multirow{2}{*}{$\begin{array}{l}\text { Change from } \\
\text { baseline }\end{array}$} & \multicolumn{2}{|c|}{ GUS 100mg Q4W } & \multicolumn{2}{|c|}{ GUS 100mg Q8W } & \multirow{2}{*}{$\begin{array}{c}\text { PBO } \\
\text { (W0-24) } \\
\\
\text { W24 }\end{array}$} & \multirow{2}{*}{$\begin{array}{c}\text { PBO } \rightarrow \\
\text { GUS } \\
100 \mathrm{mg} \\
\text { Q4W } \\
(\text { W24-52) } \\
\text { W52 }\end{array}$} \\
\hline & W24 & W52 & W24 & W52 & & \\
\hline Absenteeism, $\mathrm{N}$ & 145 & 145 & 147 & 147 & 162 & 163 \\
\hline LSmean & $\begin{array}{c}-3.4 \\
(-6.5,-0.3)\end{array}$ & $\begin{array}{c}-4.1 \\
(-6.8,-1.5)\end{array}$ & $\begin{array}{c}-3.0 \\
(-6.0,0.1)\end{array}$ & $\begin{array}{c}-4.0 \\
(-6.6,-1.3)\end{array}$ & $\begin{array}{c}-3.0(-6.0 \\
0.04)\end{array}$ & $\begin{array}{c}-3.0 \\
(-5.5,-0.4)\end{array}$ \\
\hline Diff vs. PBO & $\begin{array}{c}-0.4 \\
(-4.6,3.8)\end{array}$ & & $\begin{array}{c}-0.01(-4.2 \text {, } \\
4.2)\end{array}$ & & & \\
\hline $\begin{array}{l}\text { Presenteeism, } \mathbf{N} \\
\text { LSmean }\end{array}$ & $\begin{array}{l}145 \\
-20.1\end{array}$ & $\begin{array}{c}145 \\
-22.4\end{array}$ & $\begin{array}{c}147 \\
-19.6\end{array}$ & $\begin{array}{c}147 \\
-25.7\end{array}$ & $\begin{array}{c}162 \\
-10.5\end{array}$ & $\begin{array}{c}163 \\
-18.5\end{array}$ \\
\hline & $(-23.7,-16.6)$ & $\begin{array}{c}(-26.3,- \\
18.6)\end{array}$ & $\begin{array}{c}(-23.2,- \\
16.1)\end{array}$ & $(-29.5,-21.8)$ & $(-13.9,-7.0)($ & $(-22.2,-14.7)$ \\
\hline Diff vs PBO & $\begin{array}{c}-9.7^{\star} \\
(-14.4,-5.0)\end{array}$ & & $\begin{array}{c}-9.2^{\star} \\
(-13.9,-4.5)\end{array}$ & & & \\
\hline $\begin{array}{l}\text { Work productivity, N } \\
\text { LSmean }\end{array}$ & $\begin{array}{c}145 \\
-20.1\end{array}$ & $\begin{array}{c}145 \\
-22.6\end{array}$ & $\begin{array}{l}147 \\
-19.2\end{array}$ & $\begin{array}{c}147 \\
-25.9\end{array}$ & $\begin{array}{c}162 \\
-10.6\end{array}$ & $\begin{array}{r}163 \\
-17.6\end{array}$ \\
\hline & $(-24.1,-16.1)$ & $\begin{array}{c}(-26.8,- \\
18.3)\end{array}$ & $\begin{array}{l}(-23.1,- \\
15.2)\end{array}$ & $(-30.0,-21.7)$ & $(-14.4,-6.8)($ & $(-21.7,-13.6)$ \\
\hline Diff vs PBO & $\begin{array}{c}-9.5^{\star} \\
(-14.8,-4.2)\end{array}$ & & $\begin{array}{c}-8.6^{\star} \\
(-13.9,-3.3)\end{array}$ & & & \\
\hline Non-work Activity, N & 242 & 242 & 246 & 246 & 245 & 245 \\
\hline LSmean & -20.5 & -25.7 & -21.2 & -25.4 & -9.9 & -22.3 \\
\hline & $(-23.3,-17.7)$ & $\begin{array}{c}(-28.6,- \\
22.7)\end{array}$ & $\begin{array}{c}(-23.9,- \\
18.4)\end{array}$ & $(-28.4,-22.5$ & $(-12.6,-7.1)$ & $(-25.3,-19.4)$ \\
\hline Diff vs PBO & $\begin{array}{c}-10.6^{*} \\
(-14.4,-6.8)\end{array}$ & & $\begin{array}{c}-11.3^{\star} \\
(-15.1,-7.5)\end{array}$ & & & \\
\hline
\end{tabular}

$\mathrm{Cl}=$ Confidence interval

a. LSmean for each MI dataset is calculated based on an ANCOVA model for the change from baseline at W24/W52. The combined LSmean, which is the average of the LSmean, taken over all the MI datasets, is presented.

${ }^{*} \mathrm{p}<0.05$
Flgure. Shift Analysis of Working Status: Not Employed at Baseline

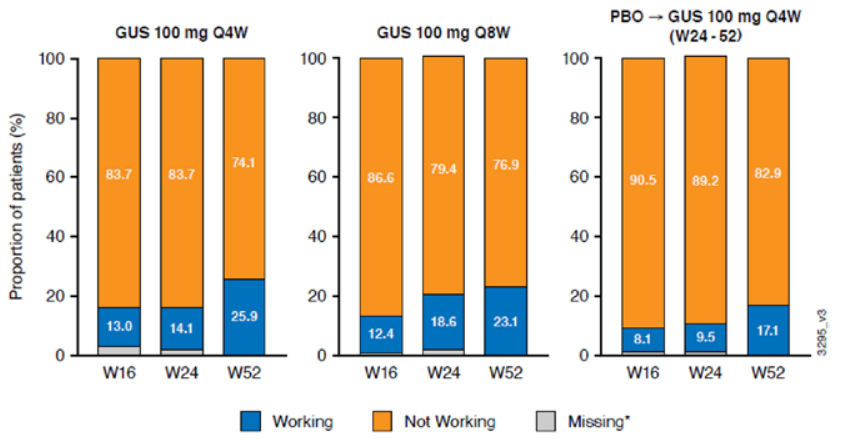

GUS $100 \mathrm{mg}$ O4W ( $(\mathrm{N}=92)$, GUS $100 \mathrm{mg}$ Q8W (N = 97), PBO $\rightarrow$ GUS $100 \mathrm{mg}$ Q4W (W24-52) $(\mathrm{N}=74)$

"GUS $100 \mathrm{mg}$ OAW: W16, 3.3\%; W24, 2.2\%, GUS $100 \mathrm{mg}$ O8W: W16, 1.0\%; W24, 2.1\%. PBO $\rightarrow$ GUS $100 \mathrm{mg}$ O4W (W24-52:

Disclosure of Interests: Jeffrey Curtis Consultant of: AbbVie, Amgen, Bristol-Myers Squibb, Corrona, Janssen, Lilly, Myriad, Pfizer, Regeneron, Roche, and UCB, Grant/research support from: AbbVie, Amgen, Bristol-Myers Squibb, Corrona, Janssen, Lilly, Myriad, Pfizer, Regeneron, Roche, and UCB, lain McInnes Consultant of: AbbVie, Bristol-Myers Squibb, Celgene, Eli Lilly and Company, Gilead, Janssen, Novartis, Pfizer, and UCB, Grant/research support from: Bristol-Myers Squibb, Celgene, Eli Lilly and Company, Janssen, and UCB, Steve Peterson Shareholder of: Johnson \& Johnson, Employee of: Janssen Global Services, LLC, Prasheen Agarwal Shareholder of: Johnson \& Johnson, Employee of: Janssen Research \& Development, LLC, Feifei Yang Shareholder of: Johnson \& Johnson, Employee of: Janssen Global Services, LLC, Alexa Kollmeier Shareholder of: Johnson \& Johnson, Employee of: Janssen Research \& Development LLC, Elizabeth C Hsia Shareholder of: Johnson \& Johnson, Employee of: Janssen Research \& Development, LLC, Chenglong Han Shareholder of: Johnson \& Johnson, Employee of: Janssen Research \& Development, LLC, William Tillett Speakers bureau: AbbVie, Amgen, Celgene, Lilly, Janssen, Novartis, Pfizer Inc, and UCB, Consultant of: AbbVie, Amgen, Celgene, Lilly, Janssen, Novartis, MSD, Pfizer Inc, and UCB, Grant/research support from: AbbVie, Celgene, El Lilly, Janssen, Novartis, Pfizer Inc, and UCB, Philip J Mease Speakers bureau: Boehringer Ingelheim and GlaxoSmithKline, Grant/research support from: AbbVie, Amgen, Bristol Myers Squibb, Eli Lilly, Galapagos, Gilead, Janssen, Novartis, Pfizer, SUN, and UCB, Proton Rahman Speakers bureau: AbbVie, Eli Lilly, Janssen, Novartis, Pfizer, and UCB, Consultant of: AbbVie, Amgen, Bristol Myers Squibb, Celgene, Eli Lilly, Janssen, Novartis, Pfizer, Roche, and UCB, Grant/ research support from: Janssen and Novartis.

DOI: 10.1136/annrheumdis-2021-eular.244

\section{POS1027 EFFICACY AND SAFETY OF GUSELKUMAB, A MONOCLONAL ANTIBODY SPECIFIC TO THE P19- SUBUNIT OF INTERLEUKIN-23, THROUGH 2 YEARS: RESULTS FROM A PHASE 3, RANDOMIZED, DOUBLE- BLIND, PLACEBO-CONTROLLED STUDY CONDUCTED IN BIOLOGIC-NAÏVE PATIENTS WITH ACTIVE PSORIATIC ARTHRITIS}

I. Mcinnes ${ }^{1}$, P. Rahman ${ }^{2}$, A. B. Gottlieb ${ }^{3}$, E. C. Hsia $^{4,5}$, A. Kollmeier ${ }^{4}$, X. L. Xu ${ }^{4}$, S. Sheng ${ }^{6}$, Y. Jiang ${ }^{6}$, M. Shawi ${ }^{7}$, S. D. Chakravarty ${ }^{8,9}$, D. Van der Heijde ${ }^{10}$, P. J. Mease ${ }^{11}$. ${ }^{1}$ University of Glasgow, Institute of Infection, Immunity and Inflammation, Glasgow, United Kingdom; ${ }^{2}$ Memorial University of Newfoundland, Craig L Dobbin Genetics Research Centre, St. John's, Canada; ${ }^{3}$ Icahn School of Medicine Mt. Sinai, Dermatology, New York, United States of America; ${ }^{4}$ Janssen Research \& Development, LLC, Immunology, Spring House, United States of America; ${ }^{5}$ University of Pennsylvania Medical Center, Rheumatology, Philadelphia, United States of America; 6 Janssen Research \& Development, LLC, Biostatistics, Spring House, United States of America:

${ }^{7}$ Janssen Scientific Affairs, LLC, Immunology, Horsham, United States of America; ${ }^{8}$ Janssen Scientific Affairs, LLC, Immunology, Horsham, United States of America; ${ }^{9}$ Drexel University College of Medicine, Rheumatology, Philadelphia, United States of America; ${ }^{10}$ Leiden University Medical Center, Rheumatology, Leiden, Netherlands; ${ }^{11}$ Swedish Medical Center/Providence St. Joseph Health and University of Washington, Rheumatology Research, Seattle, United States of America

Background: Guselkumab (GUS), a selective IL-23 inhibitor dosed every 4 or 8 weeks (Q4W or Q8W), demonstrated efficacy for joint and skin symptoms, inhibition of structural damage progression (Q4W), and safety vs. placebo (PBO) through Week 24 (W24) of the Ph3, double-blind, PBO-controlled trial in biologic-naïve pts with PsA (DISCOVER-2). ${ }^{1}$ Favorable benefit-risk was also seen through 1 year. $^{2}$

Objectives: To assess GUS efficacy and safety through 2 years. 